\title{
Students' Perception Toward English e-Learning During Covid-19 Pandemic: A Study of the Tenth Graders of SMA Negeri 3 Palangka Raya
}

\author{
Abrar Januar Rifaldi ${ }^{*}$, Wahyuningsih Usadiati ${ }^{2}$, Maria Arina Luardini ${ }^{3}$ \\ 1,2, ${ }^{3}$ The Study Program of English Education, Faculty of Teacher Training and Education \\ University of Palangka Raya
}

\begin{abstract}
E-learning has become a mandatory component of all educational institutions as has been decided by the Indonesian goverment during the COVID-19 pandemic emergency period. Policy has demanded that educational institutions should be able to ensure the teaching and learning process that is usually carry out through face to face is transformed into E-learning in order to avoid spreading the virus COVID-19 to students, teachers and other related parties. Even with all the lexisting imitations and constraints, E-Learning must be applie by all levels of education, including the process of English E-Learning. The purpose of this study was to know the students' perception toward English E-Learning during COVID-19 pandemic and how it impacts students' motivation to join the online learning during pandemic. The method of this research was desciptive qualitative research. The data were collected through questionaires, interviews, and documentations from 223 respondents of grade X SMA Negeri 3 Palangka Raya. Questionnaire was compiled in Google Form and distributed to students via Whatsapp. Interview was conducted through conversation via WhatsApp and documentation was also done by collecting related government policies with E-Learning during pandemic and document related to the research subject. The findings of this study indicated that students' perception toward English E-Learning during pandemic was positive, and this has an impact on students' motivation to join the teaching and learning process well during pandemic. In conclusion, English E- Learning during pandemic has provided very valuable experience for teachers, students and other related parties wich can be used as reference to develop hybrid models of teaching in Senior High Schools.
\end{abstract}

Keywords: students' perception, e-learning, covid-19 pandemic

\section{INTRODUCTION}

Covid-19 pandemic which began to plague in China on December 2019 has an impact on the spread of the virus almost all over the world and Indonesia is no exception. On 2nd March 2020, the spread of Covid-19 began to be detected in Indonesia. According to Kompas.com (2020), until the last Desember 2020, the total of coronavirus asses in Indonesia reaches 743.198 cases and probably will continue to grow. The same with the other cities, the coronavirus is also detected in Palangka Raya.

In the field of education, the Minister of Education and Culture, Nadiem Anwar Makarim, issued Circular Number 4 of 2020 concerning the Implementation of Education in Emergency Coronavirus (Covid-19). One of which is the emphasis that online learning (distance) is to be carried out to provide meaningful learning experiences for students. It is noted that the learning activities and tasks can vary among students according to their interests and conditions, including in terms of gaps in access learning facilities at home.

\footnotetext{
*Corresponding author: abrar.rifaldi@gmail.com

To cite this article: Rifaldi, A.J., Usadiati, W., \& Luardini, M.A. (2021). Students' Perception Toward English e-Learning During Covid-19 Pandemic: A Study of the Tenth Graders of SMA Negeri 3 Palangka Raya.

Ebony --- Journal of English Language Teaching, Linguistics, and Literature, 1 (1) 2021, pp. 34--53.
} 
The policy above has demanded that educational institutions are able to ensure that the teaching and learning process that is usually carry out through face to face is transformed into E learning in order to avoid spreading the virus to students and teachers and other related parties. The impact is not only on the field of public health but almost all aspects of life, such as industry, trade, food and others, including the field of education.

Therefore, during the COVID-19 pandemic emergency period wich began in March 2020, the teaching and learning activities in the city of Palangka Raya are being implemented through E learning, no exception for English lessons at the High School level, including SMA Negeri 3 Palangka Raya. Unfortunately, in Indonesia, especially in Palangka Raya, not all students are familiar with the E-Learning system, so this has become a new challenge that requires adaptation.

Meanwhile, according to Institute Saiful Murjani Research and Consulting (SMRC), released at Kompas.com and voi.id (2020), the results of research towards online learning activities during pandemic show that as many as $24 \%$ of respondents claimed to have no internet access. It means there was no internet network that reached where they live, or they did not have a platform to access the internet. However, $76 \%$ of the respondents stated that they had internet access for distance learning during the Covid-19 pandemic. Besides that, it was found in the survey that $92 \%$ respondents experienced many distractions while learning through online mode.

Considering the very rapid development of information technology nowadays, this study is based on the argumentation that the E-learning Models cannot only be implemented in the situation of Covid-19 pandemic but also as an alternative and innovative learning model. After Covid-19 pandemic ends, E-Learning model is still needed to be combined with face-to-face learning model. According to Brown and Feasy (in Darmawan, 2014), stated that E-Learning is a learning activity that utilizes the internet network as delvery method, interaction, and facilities and is supported by various form of learning services. Furthermore, Indrakusuma and Putri (2016) stated that E-Learning is an abbreviation of Electronic Learning which is one of the new ways in the teaching and learning process and uses electronic media specifically the internet as a learning system. Through E-Learning, material provided to students can be accessed anytime and from anywhere, in addition to getting material that can be enriched or equipped with a variety of supporting learning resources including multimedia that can be supported by teachers (Suartama, 2014). From the various statements above, it can be restated that E-Learning is the teaching and learning model that utilizes electronic media especially the internet. This model of learning make it easy for teacher because can be carried out anytime and anywhere.

So far, the studies of E-learning tend to discuss learning models based on three perspectives. First, studies examining the issue of online learning as new learning media systems that encourage the implementation of more effective learning. Second, a study of E-learning that provides convenience for learners in accessing learning material. And third, studies that pay attention to the issue that online learning is a complement that combines some of the best aspects of conventional learning (face-to-face) and online information and communication technology-based learning (Wargadinata et al. 2020). 
The present research tried to investigate the students' perception on English ELearning which has been applied in their education and how it gave impacts on the students' motivation to join the teaching and learning processes through E learning. In other words, the researcher wanted to know that in the midst of the Covid-19 pandemic whether students were still learning well or not through the E-Learning system applied at school. This is based on the very strict health protocol required that all outdoor activities must be reduced, including the teaching and learning process that must be done from home through online model. This thing might affect the students' motivation to join the learning and teaching processes.

\section{METHODS}

This research was a qualitative descriptive research. The data used in this research were obtained from questionnaire distributed via Google forms to the tenth graders of SMA Negeri 3 Palangka Raya as the respondents, online interviews through social media with selected students as respondents, and documentation.

The questionnaires consisted of 15 questions asking about the students' perception and how it impacts their motivations toward English E Learning during Pandemic COVID19. From the distribution of questionnaires that came in, there were 223 responses from the students as the respondents of the research.

Standardized open-ended interviews followed Cohen et al. (2011) were conducted through conversations via Whatsapp (WA) with 12 respondents based on convenience sampling who were selected for they were convenient and available (Cherry, 2020). The interview questions were taken from the questionnaire to find out more in-depth information with additional questions to support the data obtained from the questionnaire. Documentation was taken including several policies issued by the government during COVID-19 emergency related with E learning and research subject document.

\section{RESULTS}

The research results are taken from the results of questionnaire, interview and documentation. They are given as follows. The total data from the results of questionnaire filled in and sent by students to the researcher were 223 respondents via Google form.

The questions in the questionnaire were compiled to answer two research problems of the students' perception toward English E-learning during Pandemic COVID-19 and the students' motivation toward English E-Learning during Pandemic COVID-19. For the above purpose, the researcher compiled the questions into fifteen questions and divided them into two main groups, i.e. the questions related to students' perception of learning English by E-Learning which consisted of 6 questions and the second group was the questions related to student motivation towards learning English online during pandemic with 7 questions. In addition, there were two questions that were related to the most frequently used applications and what device were most often used during online learning to find out student preferences in using supporting device and application programs for smooth online learning. 
From the data in figure 1 below, it can be seen that the number of respondents based on their major is 223 students with the composition of MIPA students (48.4\%), IPS students $(43.5 \%)$, and Bahasa students $(8.1 \%)$.

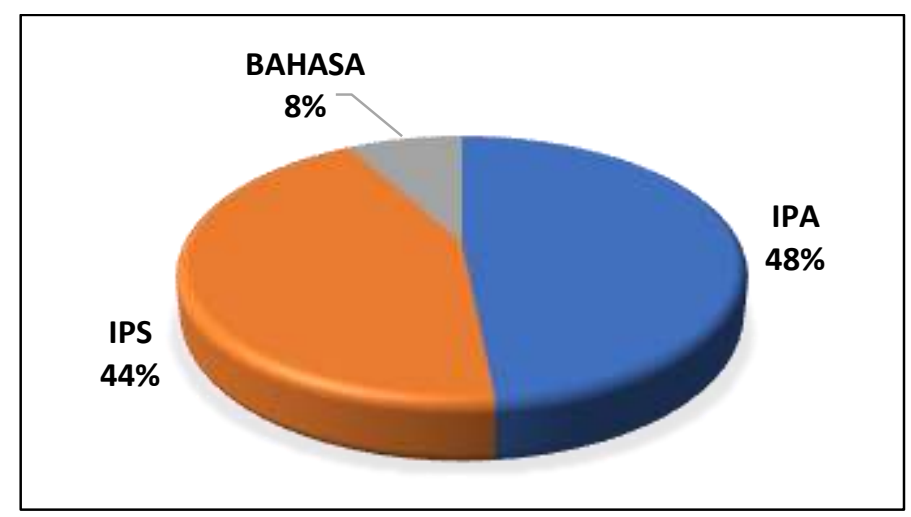

Fig 1. Respondents' answers based on the majors

Questionnaire data results for each of these groups are presented in the following explanation. The first group of data was data from questionnaire to answer the first research problem, i.e. about the students' perception towards English E learning during the Pandemic COVID-19, which consisted of six (6) questions. The first question was about the Effectiveness, the second was about Material Delivered, the third was about the Best Choice, the fourth was about Readiness, the fifth was about the Need of English ELearning, and the sixth was about Internet Access. The second group of data was to answer the second research problems, i.e. their motivation in learning English through Elearning during COVID-19 pandemic. The questions consisted of 7 questions which were simplified into question number one about Happy Feeling, number two about Motivation, number three about Boredom, number four about Asking to the Teacher, number five about Willingness to Learn, number six Doing Assignment, and number seven about Consistency. Those are all related to the use of English E-Learning during Pandemic COVID-19. All of the data are shown in the tables 1 and 2 below.

Table 1. The data of Questionnaire Results of the Student's Perception of English E-Learning

\begin{tabular}{|c|c|c|c|c|c|c|}
\hline \multirow{2}{*}{ NO. } & \multirow{2}{*}{ Description } & \multicolumn{4}{|c|}{ Answers } & \multirow{2}{*}{ Total } \\
\hline & & Yes & No & Maybe & Dont Know & \\
\hline \multirow[t]{2}{*}{1} & $\begin{array}{l}\text { Learning English through E- } \\
\text { learning can improve my English } \\
\text { skills. }\end{array}$ & 69 & 17 & 126 & 11 & 223 \\
\hline & Percentage & 30,9 & 7,6 & 56,5 & 4,9 & 100 \\
\hline 2 & $\begin{array}{l}\text { The teacher explains the English } \\
\text { material through E-learning well. }\end{array}$ & 177 & 4 & 40 & 2 & 223 \\
\hline & Percentage & 79,4 & 1,8 & 17,9 & 0,9 & 100 \\
\hline
\end{tabular}




\begin{tabular}{|c|c|c|c|c|c|c|}
\hline 3 & $\begin{array}{l}\text { English E-learning model is the } \\
\text { best choice during pandemic. }\end{array}$ & 99 & 35 & 76 & 13 & 223 \\
\hline & Percentage & 44,4 & 15,7 & 34,1 & 5,8 & 100 \\
\hline \multirow[t]{2}{*}{4} & $\begin{array}{l}\text { English E-learning model is not } \\
\text { ready if it is fully applicated in } \\
\text { SMA. }\end{array}$ & 60 & 27 & 94 & 42 & 223 \\
\hline & Percentage & 26,9 & 12,1 & 42,2 & 18,8 & 100 \\
\hline \multirow[t]{2}{*}{5} & $\begin{array}{l}\text { Learning English through E- } \\
\text { learning is still needed after the } \\
\text { pandemic ends but it should be } \\
\text { combined by the face-to-face. }\end{array}$ & 95 & 46 & 58 & 24 & 223 \\
\hline & Percentage & 42,6 & 20,6 & 26 & 10,8 & 100 \\
\hline 6 & $\begin{array}{l}\text { When I learn English through E- } \\
\text { learning I found the difficulties } \\
\text { in accessing the internet. }\end{array}$ & 113 & 66 & 44 & 0 & 223 \\
\hline & Percentage & 50,7 & 29,6 & 19,7 & 0 & 100 \\
\hline
\end{tabular}

Table 2. The data of Questionnaire Results of the Students' Motivation toward English ELearning

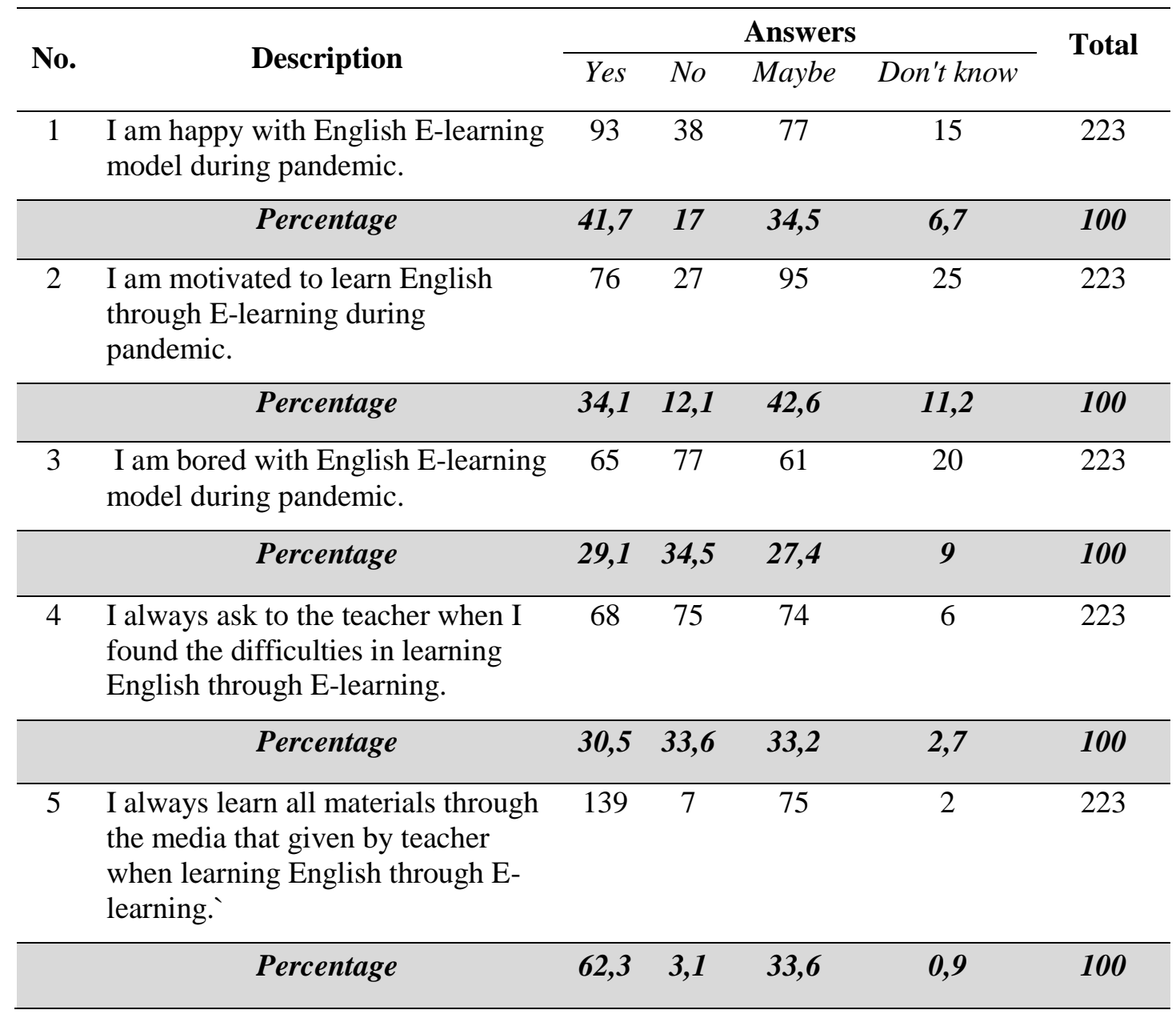




\begin{tabular}{ccccccc}
\hline 6 & $\begin{array}{l}\text { I always do all of tasks that given } \\
\text { by teacher when learning English } \\
\text { through E-learning. }\end{array}$ & 194 & 1 & 27 & 1 & 223 \\
\hline Percentage & $\mathbf{8 7}$ & $\mathbf{0 , 4}$ & $\mathbf{1 2 , 1}$ & $\mathbf{0 , 4}$ & $\mathbf{1 0 0}$ \\
\hline $7 \begin{array}{l}\text { I still learn English through E- } \\
\text { learning despite no one tasks from } \\
\text { teacher. }\end{array}$ & 92 & 33 & 92 & 6 & 223 \\
\hline Percentage & $\mathbf{4 1 , 3}$ & $\mathbf{1 4 , 8}$ & $\mathbf{4 1 , 3}$ & $\mathbf{2 , 7}$ & $\mathbf{1 0 0}$ \\
\hline
\end{tabular}

In addition, there were additional data related to the most preferred applications and devices used during online learning. This was collected to find out student preferences in the use of supporting device and application programs for smooth online learning during a pandemic. They are stated in table 3 as follows:

Table 3. Students' Preference of Application Program and Device in English E-learning

\begin{tabular}{llll}
\hline No & Description & Freq. & Percentage \\
\cline { 1 - 2 } & The kind of applications that I mostly like when learning &
\end{tabular}

1. The kind of applications that I mostly like when learning English through E-learning.

\begin{tabular}{lll} 
a. Zoom & 43 & 19,3 \\
\hline b. Google Classroom & 125 & 56,1 \\
\hline c. Whatsapp & 14 & 6,3 \\
\hline d. You tube & 41 & 18,4 \\
\hline e. Mail & 0 & 0 \\
\hline Total & $\mathbf{2 2 3}$ & $\mathbf{1 0 0}$
\end{tabular}

2. The kind of devices that I mostly use when learning English through E-learning.

\begin{tabular}{lll}
\hline a. Laptop & 7 & 3,1 \\
\hline b. Mobil Phone & 125 & 56,1 \\
\hline c. Desktop & 0 & 0 \\
\hline d. Laptop dan Mobil Phone & 85 & 38,1 \\
\hline e. Desktop dan mobile Phone & 5 & 2,2 \\
\hline Total & $\mathbf{2 2 3}$ & $\mathbf{1 0 0}$
\end{tabular}




\section{DISCUSSION}

Based on the results of questionnaire, interview and documentation as stated in the previous tables, the discussion that follows is the discussion about the students' perception and how it impacts to the students' motivation toward the use of English E-Learning during the COVID-19 pandemic.

\section{A. Students Perception}

\section{Effectiveness of English E-Learning}

The effectiveness of English E-Learning viewed from the students' perception is pictured as follows.

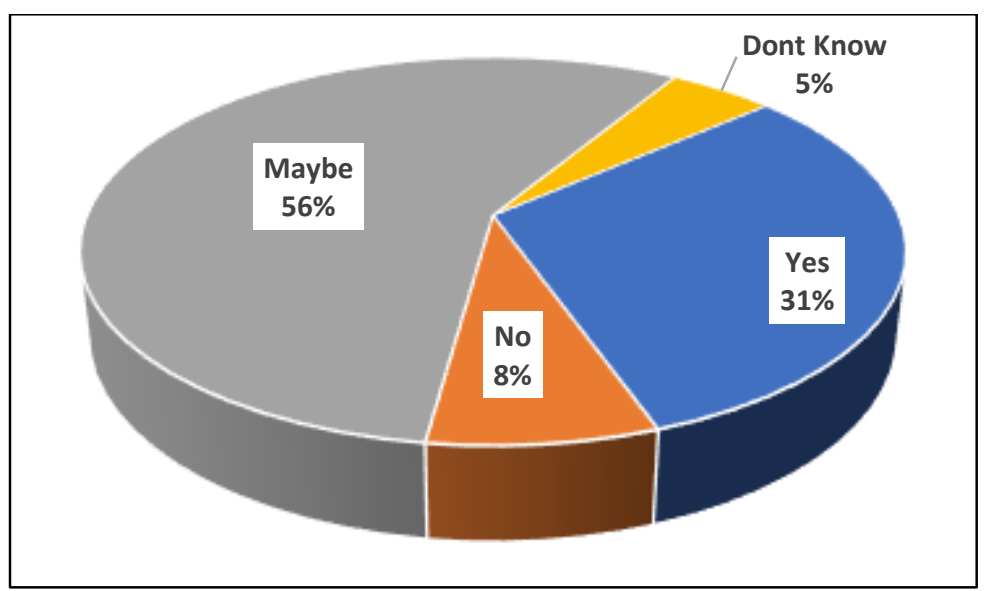

Fig. 2 Effectiveness of English E-Learning

It was found that there was $56.5 \%$ of the respondents who answered 'Maybe'. In other words, there are doubts from respondents they did not clearly state 'yes' or 'no' whether the E-learning was effective to improve their English language skills.

If it is seen from the results of the interview conversations, the matters above are not much different. However, when compared with the Student English Score data, for the first semester of the 2020-2021 school year,the English scores of grade X students of SMA Negeri 3 Palangka Raya in were $96 \%$ of students whose English score was above the KKM (Minimum Mastery Criteria) and students who got the same score or below the KKM with the 70-75 value group were 13 (4\%) students. So it can be concluded that although the respondents were doubtful whether online learning during the pandemic can improve their English, the fact is that these doubts are not reflected in the findings from the data on their semester scores.

\section{Material Delivered}

The material delivered during English E-learning viewed from the students' perception is pictured as follows. 


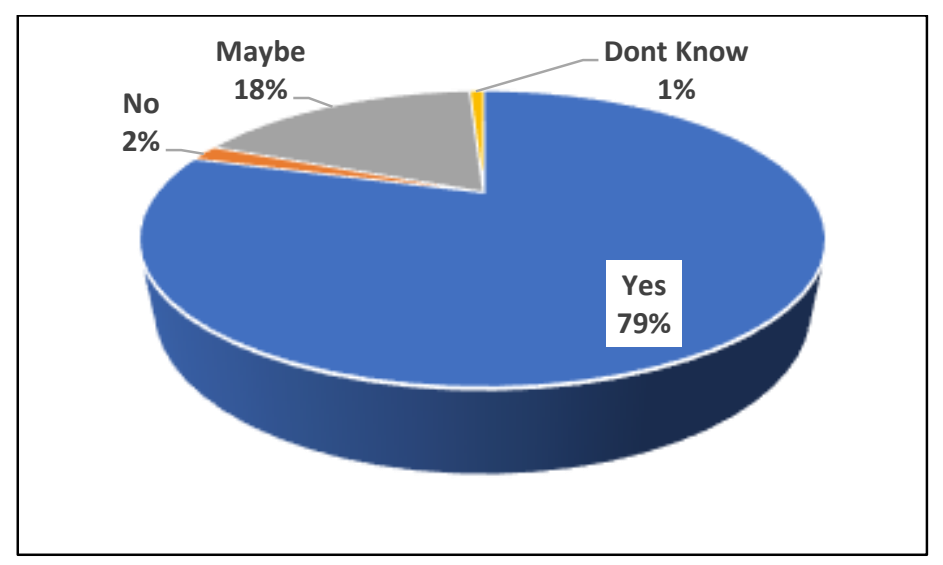

Fig. 3 Material Delivered in English E-Learning

From the data above it was found that from 223 respondents, it can be seen that the teacher's ability to explain the material was recognized by the respondents with a very dominant percentage, i.e., 79.4\%, which was good. However, from the data from the interview conversations there are 12 informants who answered the questions about this, they dominantly said that they did not understand the material presented by the teacher, it means that even though the teacher was good at delivering the material, the informant still did not fully understand the subject matter taught by the teacher.

When the researcher asked what the reason for their lack of understanding, the given answers were almost the same, i.e., limitations for respondents to understand because they felt that the teacher's explanation was not enough to just be delivered, but there were more things that had to be explained by the teacher which could not be fulfilled in online learning.

Actually the problem above has been anticipated by the government, because the government through the Ministry of Education and Culture has collaborated with a number of learning applications that can be accessed for free of charge. However, it seemed that this is not yet a complete solution, because when they were asked whether they learned other material besides those delivered by the teacher on the internet regarding this, eight informants stated that they had never studied other material apart from the teacher's material.

\section{The Best Choice}

Regarding to the question whether E-Learning during a pandemic is the best choice, from 223 respondents, they had answered Yes (44.4\%), No (15.7\%), Maybe (34.1\%), and Don't Know (5.8\%). This is shown in the following chart. 


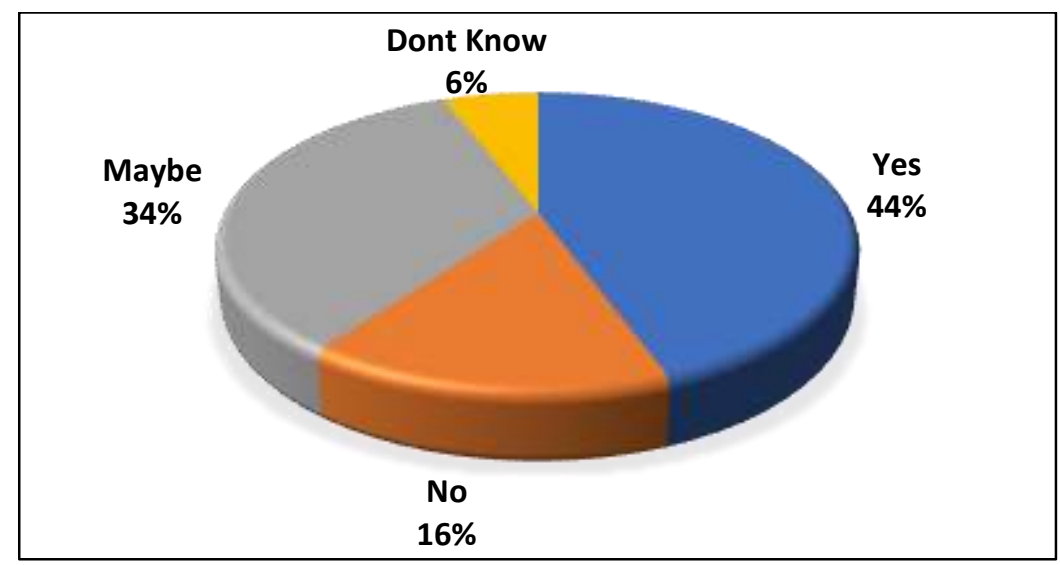

Fig 4. The Choice of English E-Learning

Regarding to the question whether E learning during a pandemic is the best choice, from 223 respondents on the data above, it can be concluded that the dominant respondent considered the online learning option during a pandemic to be the best choice. However, $34.1 \%$ of respondents were still unsure or still in doubt, even $15.7 \%$ of respondents stated that they did not agree with this choice.

If we compare it with the data from the interview conversations the dominant informant answers were No, as many as 7 informants with almost the same reasons, such as online learning is difficult to understand due to lack of interaction. From the informants' answers, it can be seen that many of them do not fully understand the purpose of online learning options during this pandemic to avoid the spread of the COVID-19 virus to students, teachers and other related parties.

Apart from this, so far we saw that the spread of the COVID-19 virus to students, teachers and other related parties can be prevented by the government's decision to carry out the teaching and learning process online during the COVID-19 emergency period.

\section{Readiness}

Regarding to the question whether learning through E learning is ready to be implemented in high school level, from the data below, From 223 respondents, they had answered Yes (26.9\%), No (12.1\%), Maybe (42.2\%) and Don't Know (18.8\%). It is shown in the following chart.

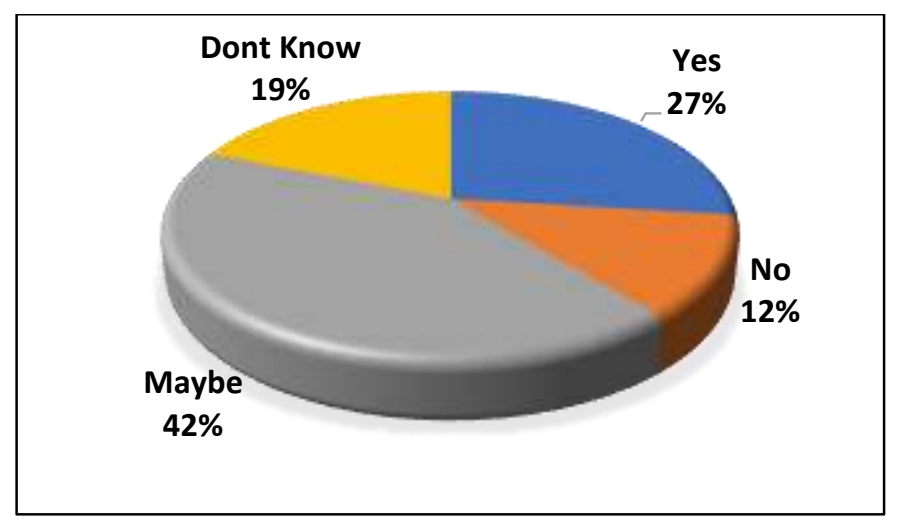

Fig. 5 Readiness of English E-Learning to be Implemented 
From the data above, we can see that even though there were $26.9 \%$ who answered Yes, there were still dominant doubts from the respondents, which can be seen from the answer of Maybe in the amount of $42.2 \%$ to this question. This doubt is understandable considering that in the answer to the previous question about Effectiveness, the respondent was not sure (Maybe (56.6\%) that the learning system as E-learning was able to improve their English language skills.

If it seen from the results of the interview of this question, it can be concluded that the informants who answered ready were 6 people and those who answered were not ready were 5 people and the rest were hesitant. But if it viewed at the reasons, from those who answered yes, there were 2 people who gave reasons that not to connect with the question and likewise for those who answered not ready. Two informants who did not connect with the questions gave the reasons because it was not possible to learn as usual during the pandemic, and because it was to prevent the spread of COVID 19.

As for the two people who answered they were not ready but their answers were not connected, they had gave reasons because this was still corona. At least, one more informant could not explain the reason. The answer was did not go together because what was being asked was a matter of readiness if E-learning was fully implemented in high school level after the pandemic.

\section{Need of English E-Learning}

Regarding to the question whether after this pandemic ends, online learning still needs to be applied and combined with face-to-face learning. From 223 respondents, they had answered Yes (42.6\%), No (20.6\%), Maybe (26\%) and Don't Know (10.8\%). This is shown in the following chart.

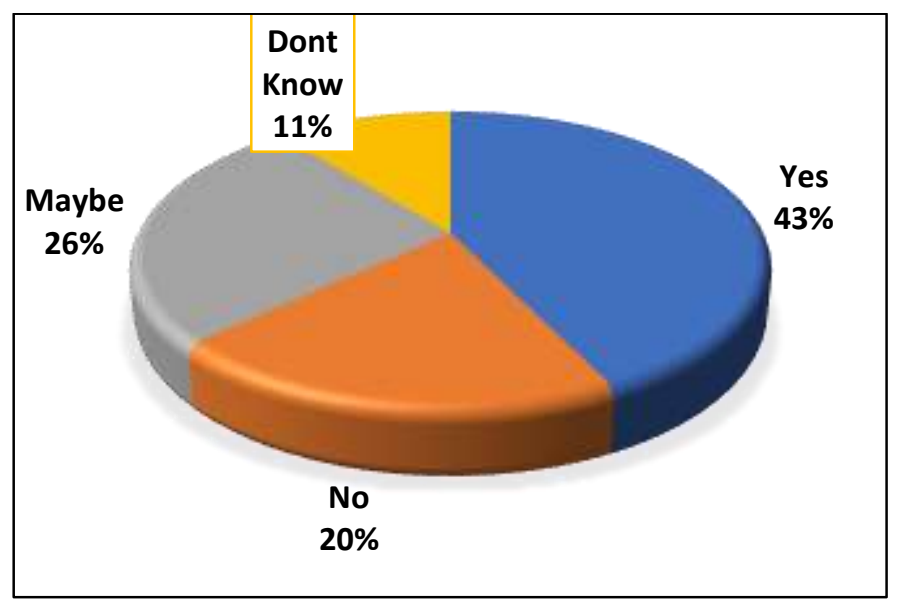

Fig. 6 The Need of English E-Learning and its Combination

Regarding to the question whether after this pandemic ends, need of English E Learning, from these data it can be concluded respondents who believed that E-learning was still needed to be applied and combined with face-to-face learning was more dominant than other answers.

The findings above are in line with the argument at the beginning of this study that the E-learning models cannot only be implemented in the situation of the Covid-19 
pandemic but it is also an alternative and innovative learning model. This means that After Covid-19 pandemic ends, the E-Learning model is still needed to be combined with faceto-face learning model.

When it viewed from the data from the existing interview conversation results, the informants said no, 8 informants said still needed, 3 informants and the rest were doubtful. This was understandable because in accordance with the data from the results of quetionnaire there were still those who answered No to this question by $20.6 \%$ or 45 respondents who might be among those who answered E-learning is not needed even though it is combined with face-to-face learning.

\section{Access to the Internet}

Regarding to the question whether during online learning during pandemic respondents had problems to access the internet, from 223 respondents, they answered Yes (50.7\%), No (29.6\%), Maybe (19.7\%) and no one answered Don't know. This is shown in the following chart.

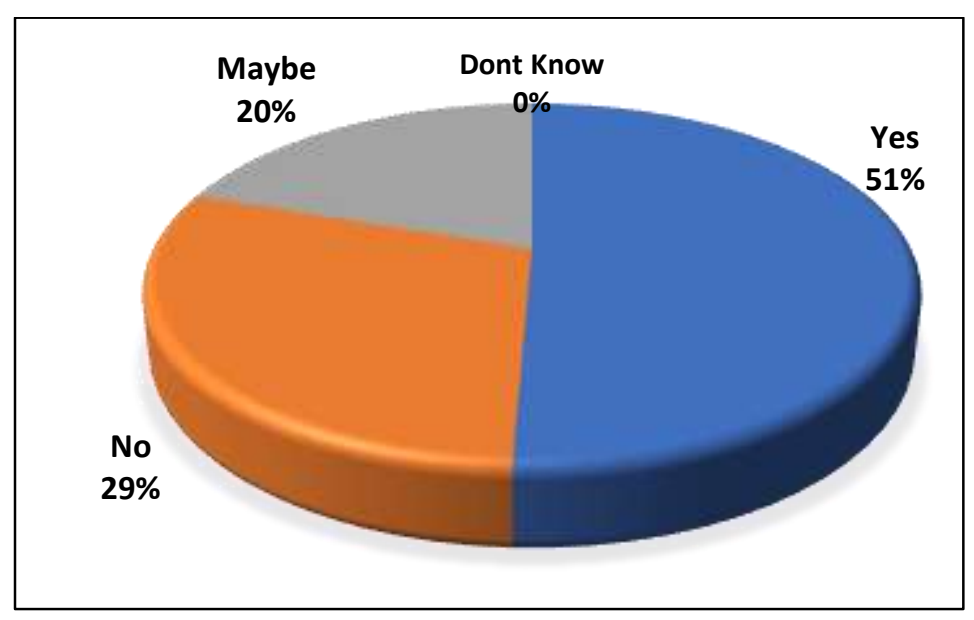

Fig. 7 Problems to Access the Internet

From these data, it can be concluded that the internet disturbance was predominantly experienced by the respondents. When it viewed from the data of the interview conversations, the internet disturbance was also predominantly experienced by informants, and the only one informant felt that there has never been an internet disturbance while studying online

The most dominant disturbance experienced by informants was caused by an unstable network and also due to the internet quota package that had run out. From the answers in the interview, disturbances regarding unstable networks were dominantly experienced by both those who used WiFi facilities or not. In addition, other disturbances are caused by the limitations of internet quota packages experienced by those who do not use wifi facilities in online learning and for those who use wifi facilities, the limitations of internet quota packages are not found.

Unfortunately, this problem is still dominantly experienced by respondents even though the government has taken a policy to overcome this problem through the policy of the Minister of Education and Culture which provides free quota packages to students, 
teachers, and lecturers for 4 months in the first semester of 2020, and continued in the second semester of 2021. However, the quota package assistance from the government was felt insufficiently to meet the needs of data users to access the internet for their learning process.

\section{B. Students Motivation}

\section{Feeling Happy}

Regarding to the question whether respondents felt happy while learning English online during the pandemic, it can be seen from the data that among 223 respondents, they had answered Yes (41.7\%), No (17\%), and Maybe (34.5.\%) and Don't Know (6.7\%). It is shown in figure 8 as follows.

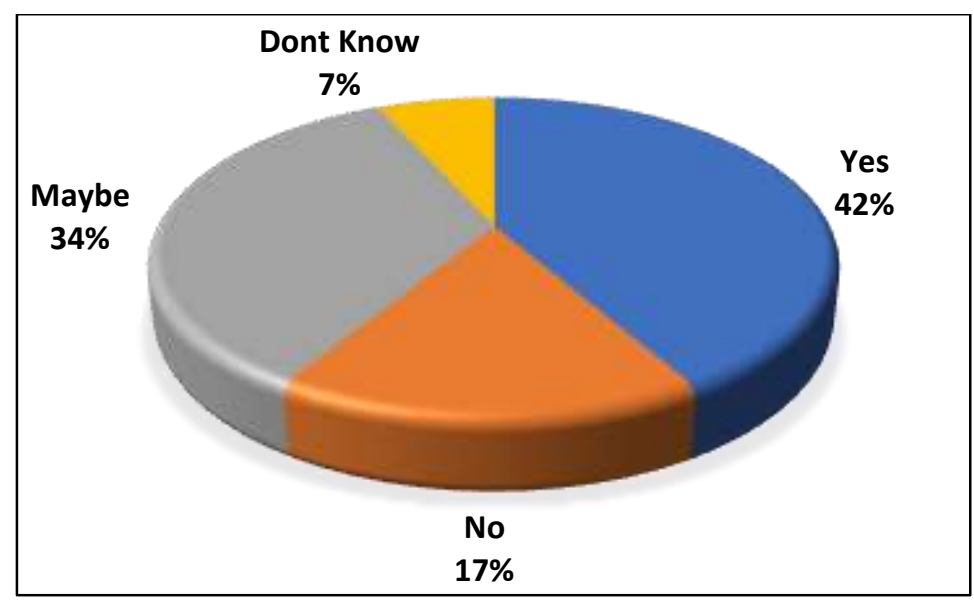

Fig. 8 The Feeling While Learning English in E-Learning

Regarding to the question whether respondents felt happy while learning English online during the pandemic, from these data, it can be concluded that the dominant respondent answered Yes. This meant that in the midst of the COVID -19 pandemic emergency, distance (online) learning during the pandemic can be a solution so that learning was maintained in the midst of an emergency situation, that can be accepted happily by most respondent.

If it viewed at the data from the interview conversations, that the dominant informant answers both of them, it meant that whether they were happy or not. The reason was they could study while relax, but they also said that they were not happy because the material felt difficult and they could not meet friends.

\section{Motivation}

Regarding to the question, whether the respondent feel motivated while learning English during pandemic, then from the data below it can be seen that, from 223 respondents, they had answered Yes (34.1\%), No (12.1\%), Maybe (42.6\%), and Don't know (11.2\%). It is shown in figure 9 as follows: 


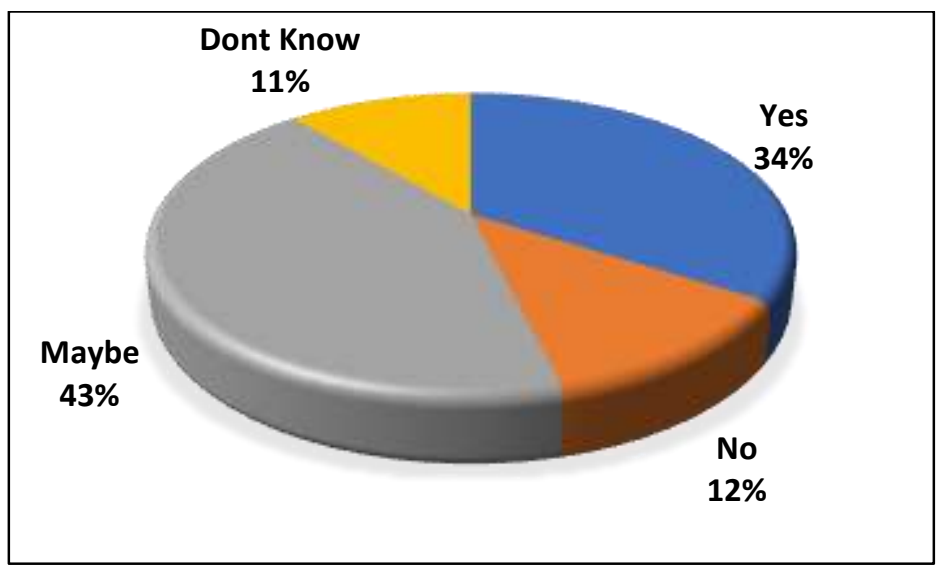

Fig. 9 Motivation towards English E-Learning

It can be seen that the dominant respondent answered Maybe, which meant that they were still hesitant to say that they felt motivated or not. This can be understood because from the start, the dominant respondents answered Maybe when the researcher were asked about effectiveness. Doubts in answering questions about effectiveness were reflected in the respondent's answers to questions about motivation.

However, when it compared with the attendance data of class X students of SMA Negeri 3 Palangka Raya during online classes in the first semester of the 2020-2021 academic year, From the total number of class X students of SMA Negeri 3 Palangka Raya, the lowest student attendance percentage is $87.7 \%$ which occurred in September 2020. and the highest is $98.9 \%$ of which occurred on July 2020. The fact that student attendance levels are still relatively high.

\section{Boredom}

Regarding to the question that is whether the respondent was bored with English ELearning during pandemic. From the data it can be concluded that from 223 respondents, they had answered Yes (29.1\%), No (34.5\%), Maybe (27.4\%), and Don't know (9\%). The data are given in figure 10 below.

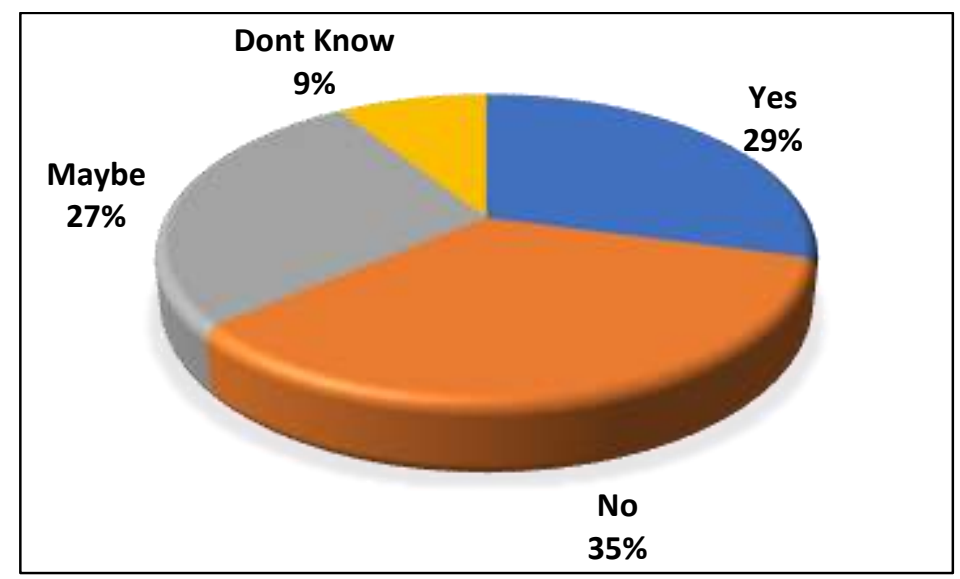

Fig. 10 Boredom toward the Use of English E-Learning 
From these data, it can be concluded that the dominant respondent answered No, which meant they were not bored to learning English through E learning during pandemic respondents still stated that learning English through E-learning during pandemic was not boring.

When compared with the interview conversation data, the dominant informant answered that he was bored for almost the same reason, namely because he had never met his friends. This is understandable because in the questionnaire to answer this question, there are 65 respondents or $29.1 \%$ who answered bored

Why the informants felt bored with learning English by E learning during the pandemic was because they could not meet their friend. So it is not because learning online is boring.

\section{Asking to the teacher}

From 223 respondents, they had answered Yes (30.5\%), No (33.6\%), Maybe (33.2\%), and Don't know $(2.7 \%)$ in asking to the teacher, as shown in the figure 11 below.

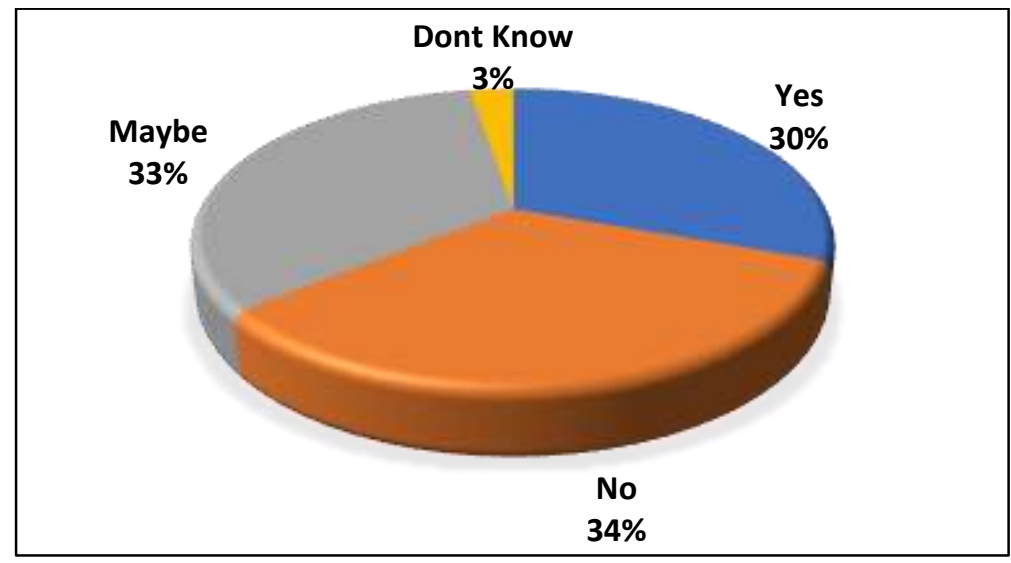

Fig. 11 Asking the Teacher

From the data above, whether the respondent always asks the teacher when they encounter difficulties while learning English during the pandemic, it can be concluded that the percentage of respondents who answered No and Maybe is the same, such as $33 \%$, so the only one respondent differs or $0.4 \%$. This is in accordance with the opinion about disadvantage of E-learning which states that E-learning students feedback is limited.

When it compared with the interview conversation data, it can be concluded that the dominant informants answered yes, so they asked the teacher even though there were some obstacles in its implementation because there were still answers from teachers whose responses were long or teachers who were difficult to contact such as the answers in the interviews that were shown in the interview data. This fact is in accordance with the findings of the questionnaire results that there are $30.5 \%$ of respondents who answered Yes, which meant that there is still a relatively large number of respondents who always ask the teacher when they have difficulty understanding the subject matter. 


\section{Willingness to learn}

Regarding the question of whether the respondent always learns the subject matter provided by the teacher when learning English by means of E-Learning during pandemic. So from the data below, among 223 respondents, they answered Yes (62.3\%), No (3.1\%), Maybe (33.6\%) and Dont know (0.9\%). It is shown in figure 12 as follows.

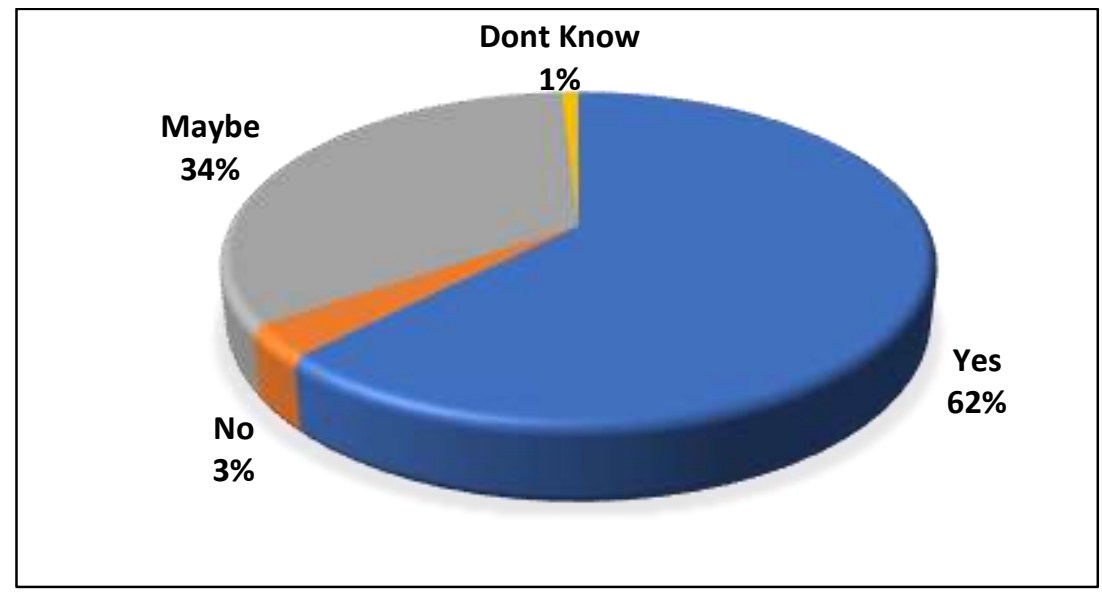

Fig. 12 Willingness to Learn the Materials from the Teacher in English E-Learning

Regarding the question of whether the respondent always learns the subject matter provided by the teacher when learning English by means of E learning during pandemic, from these data it can be concluded that the respondents answered yes very dominantly with a very large difference when compared to those who answered No.

This shows that the material provided by the teacher is still the main reference by respondents in learning English online during pandemic. Even though in the era of the current very rapid development of information technology, subject matter is very easy to find on the internet, and even the government has taken a policy by collaborating with several learning platforms that can be accessed by students for free, nevertheless respondent still makes the material provided by teachers as the main material for them to learn English lessons by means of e-learning during this pandemic. When compared with the interview data, the results are not different from the questionnaire, such as the dominant answer is yes to this question.

\section{Doing Assignment}

Regarding the question whether the respondent always did the assignment given by the teacher during learning English by means of E-Learning during pandemic, the data show that, among 223 respondents, they had answered Yes (87\%), No (0.4\%), Maybe (12.1\%) and Don't Know (0.4\%). This is shown in the following chart. 


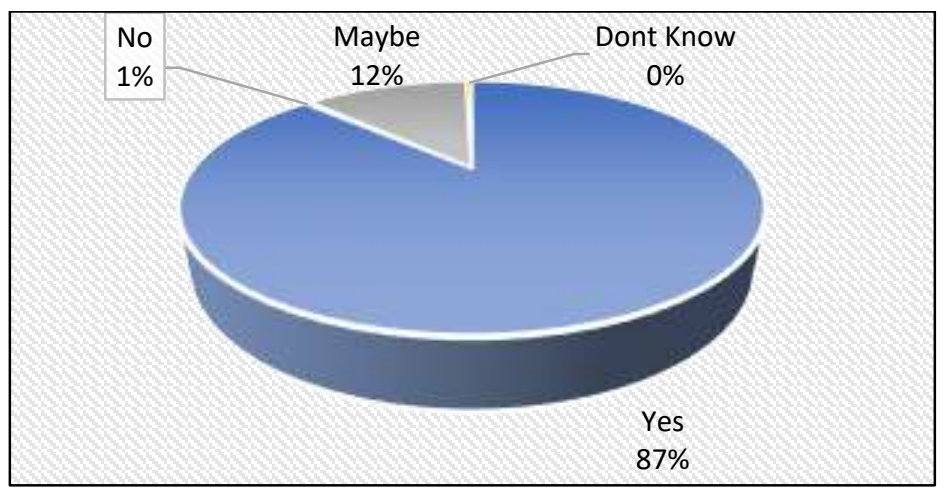

Fig. 13 Willingness to do the Assigmnent during English E-Learning

Regarding the question whether the respondent always did the assignment given by the teacher during learning English by means of E learning during pandemic, from the data, it can be concluded that the respondent is very dominant in answering Yes, and very much different from the respondent who answers No which is only $0.4 \%$. This is shown that the respondent's motivation and compliance to do the tasks that given by the teacher through E-learning during pandemic is still very high. When it compared with the data from the interview conversation results, it was not different from the questionnaire results with the dominant respondents answered yes, so they always do assignments that were given by the teacher and they will not be able to score if they do not do the assignment.

\section{Consistency}

Regarding to the question whether the respondent continued to learn English through ELearning during the pandemic even though there was no assignment from the teacher, among 223 respondents, they had answered Yes (41.3\%), No (14.8\%), Maybe (41.3\%) and Dont know (2.7\%). This is shown in the chart below.

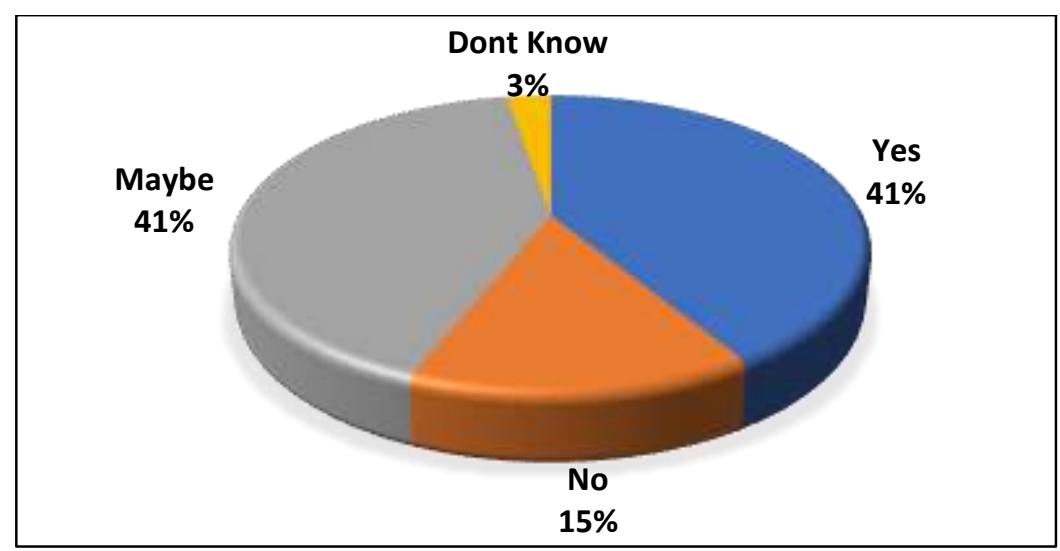

Fig. 14 Consistency to learn eventhough no assignment during English E-Learning

Regarding to the question whether the respondent continued to learn English through $\mathrm{E}$ learning during the pandemic even though there was no assignment from the teacher, from the data, it can be concluded that the number of respondents who answered Yes and Maybe was the same, such as $41.3 \%$. 
This can be interpreted that the high percentage of respondents who answered Yes to the question about Do assignment was $87 \%$ (as in the previous discussion), that were divided into respondents who answered Maybe for the questions about consistency. So, this was an indication that the assignment that was given by the teacher to students were greatly influenced the respondent's consistency in learning even though there is no assignment from the teacher. In other words, the teacher increased student motivation to continue learning consistently by giving assignments to students. When compared with the results of the interview conversations, the informants gave various answers to the question of consistency, some were still learning, sometimes they were learning and some were not learning. This is understandable considering the answers in the quetionare are also various.

\section{Students' Preference}

The next question is an additional question with the aim of knowing student preferences in learning E-Learning, especially regarding what application programs are used most often and what equipment (devices) are used most often. This is considered important because these two things are the main factors supporting the smooth running of online learning. Against this the discussion is as follows:

\section{The Application Mostly Used}

Regarding the question of what application programs were most often used in E learning during pandemic, from 223 respondents, they had answered Zoom (19.3\%), Google Classroom (56.1\%). WhatsApp (6.3\%) Youtube (18.4\%), and Mail (0\%). This is shown on the figure 15 below.

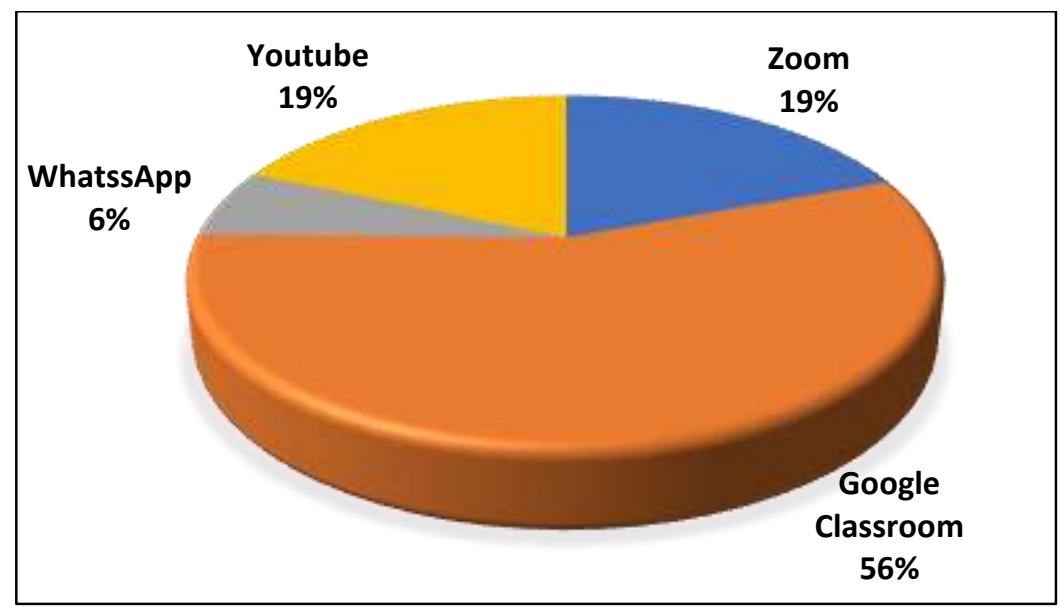

Fig. 15 The Application Programs Mostly Used in English E-Learning

Regarding to the question of whether the device was used most frequently during Elearning during pandemic, from the data above, it can be concluded that the dominant respondents used Mobile Phones as their device in English E-learning during the pandemic. When it compared with the data from the interview conversation, the informant's answer was also the same, such as the dominant use of a mobile phone on the grounds that it is easier and can be used while lying down relaxed, and indeed they only have a mobile phone and do not have any other equipment. 


\section{Device}

Regarding to the question of whether the device was used most frequently during Elearning during pandemic, from the 223 respondents, they answered Laptop (3.1\%), Mobile Phone (56.1\%), Desktop (0\%), Laptop and Mobile Phone (38.1\%) and Desktop and Mobile Phone (2.2\%). This is shown in figure 16 below.

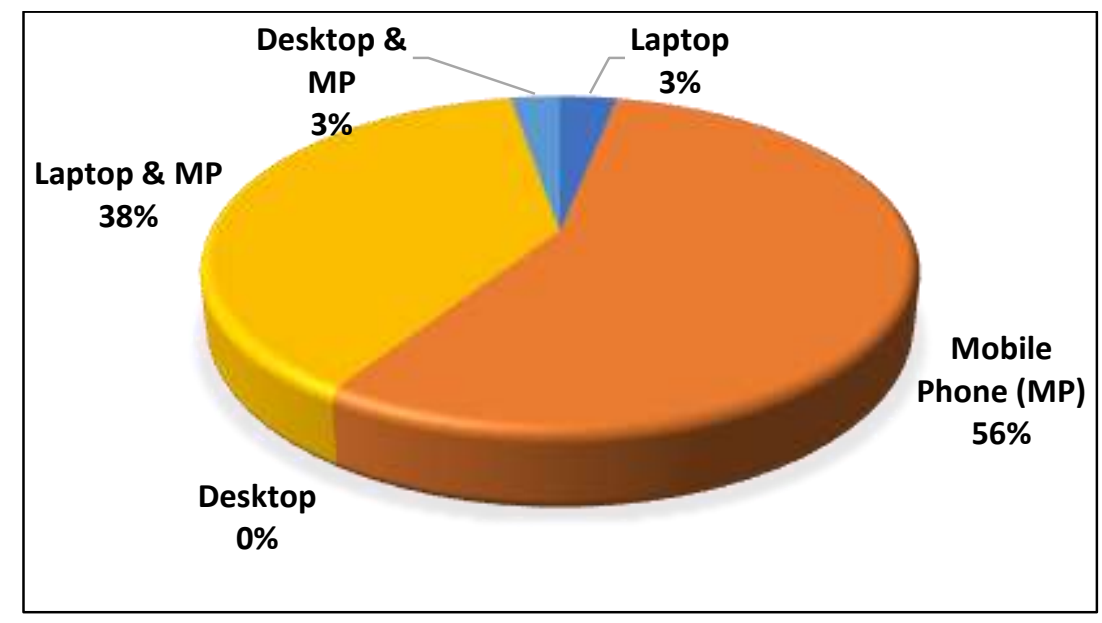

Fig. 16 The Device Mostly Used in English E-Learning

\section{CONCLUSION}

A series of policies have been taken by the government through the Ministry of Education and Culture with the aim of ensuring that during the COVID-19 emergency, the process of teaching and learning activities are carried out through E learning to avoid spreading the virus to students and teachers and other related parties can run well and smoothly.

The implementation of E learning during the COVID-19 pandemic has provided a very valuable experience in the field of education, especially at SMA Negeri 3 Palangka Raya, because teachers, students and other related parties can see, experience and feel firsthand the teaching and learning process which they have never imagined and experienced before so that it will be a very valuable knowledge for the education sector, especially in terms of the online learning system at SMA Negeri 3 Palangka Raya.

Regarding Students Perception Toward English E Learning during COVID - 19 pandemic. Although from the data on the results of the questionnaire that had been carried out, the dominant students answered doubts about the effectiveness of the question, but the fact was that the English scores of grade X students of SMA Negeri 3 Palangka Raya semester I of the 2020-2021 school year (whose learning was carried out through E learning), there are $96 \%$ of students whose scores exceed the Minimum Mastery Criteria (KKM). This gives a positive conclusion that learning by e-learning during the COVID -19 pandemic can effectively improve their English skills. Positive students' perceptions were also related to questions about material deliveries, the best choice and still needed but combine, because students were dominant in saying yes in the qurtionare and the interviews conducted. 
What should be appreciated is the finding that students are very dominant in stating that the teacher has delivered the subject matter well, even though there are few notes, namely when the material is felt difficult, they cannot fully understand it because they feel less time. Meanwhile, the finding of answers to questions about Still Needed but Combine confirms the argument at the beginning of this study that the E-learning Models cannot only be implemented in the situation of the Covid-19 pandemic but it is also an alternative and innovative learning model. This means that After Covid-19 pandemic ends, the ELearning model is still needed to be combined with face-to-face learning model (Hybrid Model).

However, there are still main obstacles related to students who are very dominant experiencing interference to access the internet because the internet signal which is often unstable experienced by students during online learning is a very important note because the main factor in implementing smooth learning through $\mathrm{E}$ learning is the availability of a stable and even internet. for the entire region.

In relation to students motivation toward english e-learning during COVID-19 pandemic, the fact that the data on the average percentage of attendance of class X students of SMA Negeri 3 Palangka Raya in the first semester of the 2020-2021 school year shows that the lowest average percentage of student attendance is $87.7 \%$ and the highest is $98.9 \%$ indicates that students are still have a relatively high motivation to take part in the learning process through E learning during the pandemic. From the results of the questionnaire, the dominant students said they were doubtful about this motivated question, this is understandable because in the previous question about the effectiveness of the students also dominant said they were doubtful.

Likewise for questions in other motivational groups such as questions about Bored, willingness to learn, and do assignment, dominant students indicated that they were still enthusiast about participating in learning through E-Learning. Although there are some that indicate the opposite, the numbers are relatively smaller.

As for the question about ask to the teacher and the consistency of the answers given by students, it indicates two different things. First, in terms of the students' desire to ask the teacher when they encounter difficulties, the dominant says no, and partially says Maybe, this indicates that the problem is that there is a lack of coummicational skill development as one of the disadvantages in E-learning, is indeed an obstacle, while for questions regarding consistency, the percentage of students who said yes and maybe were equally dominant compared to other answers, indicating that students' enthusiasm to keep learning even though there was no assignment from the teacher was still relatively good.

Regarding with student preferences, the most frequently used application program in the learning process through E-learning during the pandemic, students predominantly used Google Classroom and was followed by the Zoom application. The most important consideration of students is that they follow the direction of the teacher. As for the use of electronic devices (devices) that are most often used by students during online learning, the dominant use of mobile phones is the reason that most students have them and they are easier to use because they can learn while lying down relaxed. 


\section{REFERENCES}

Biro Kerja Sama dan Hubungan Masyarakat. 2020. Sikapi COVID-19 Kemendikbud Terbitkan Dua Surat Edaran. Jakarta: Kementerian Pendidikan dan Kebudayaaan

Cherry, K. 2020. Sample Types and Errors in Research. https://www.verywellmind.com/ what-is-a-sample-2795877. Accessed April 12, 2021.

Cohen, L., Manion, L., \& Morrison, K. 2011. Research Methods in Education. 7th ed. London: Routledge.

Darmawan, D. 2014. Pengembangan E-Learning. Bandung: PT. Remaja Rosdakarya

Indrakusuma, A. H., \& Putri, A. R. 2016. E-Learning: Teori dan Desain. Tulungagung: STKIP PGRI Tulungagung.

Kemendikbud Resmikan Kebijakan Bantuan Kuota Data Internet 2020. www.kemdikbud. go.id/main/blog/2020/09/kemendikbud-resmikan-kebijakan-bantuan-kuota-dataint

Kompas.com. 2020. Berita Terkini Hari Ini, Data Covid di Indonesia https://www. kompas.com/covid-19

Kompas.com, 2020. Survei SMRC: Belum Semua Warga Miliki Akses Internet untuk Belajar "Online": https://nasional.kompas.com/read/2020/08/18/21274711/surveismrc-belum semua-warga-miliki-akses-internet-untuk-belajar-online

Kompas.com. 2020. 12 Aplikasi Pembelajaran Daring Gratis, Kerja Sama Kemendikbud https://edukasi.kompas.com/read/2020/03/22/123204571/12-aplikasipembelajaran-daring-kerjasama-kemendikbud-gratis?page $=$ all

Suartama, I. K. 2014. E-Learning Konsep dan Aplikasinya. Singaraja: Universitas Pendidikan Ganesha.

Voice of Indonesia. 2020. Survei SMRC. https://voi.id/es/berita/11530/smrc-survey-thereare-people-who-do-not-have-internet-access-online-learning

Wargadinata, Wildana, Iffat Maimunah, Eva Dewi, Zainur Rofiq.2020. Student's Responses on Learning in the Early COVID-19 Pandemic. Tadris Journal of Education and Teacher Training, UIN Maulana Malik Ibrahim Malang, Indonesia. https:// www. researchgate.net/publication/342687222. 